\title{
Comparison of House Price Analysis in DKI Jakarta and Surabaya with Minitab Software 17.0
}

\author{
Endah Tri Wahyuningtyas ${ }^{1}$, Dina Anggraeni Susesti ${ }^{2}$ \\ ${ }^{1}$ Accounting Department, Economic and Business Faculty, University of Nahdlatul Ulama Surabaya, Surabaya 60237, \\ Indonesia \\ "Corresponding author. Email: endahtri@unusa.ac.id
}

\begin{abstract}
This article discusses the comparative analysis of factors affecting the selling price of houses between the city of DKI Jaka rta and the city of Surabaya. The study uses quantitative methods through Minitab 17.0 software. Analysis of research uses hedonic prices with data obtained from home sale sites. The findings of this study are factors that affect housing prices in Surabaya, the distance between the house and the town hall and the main road, electrical, namely the amount of electric power, land area, distance between the house and public facilities, and information on the quality of housing materials. While the factor determining the selling price of houses in DKI Jakarta is the distance between the house and the main road, land area, PDAM water and road type or the type of road location of the house.
\end{abstract}

Keywords: House price, prediction, comparison

\section{INTRODUCTION}

The development of the business world is growing rapidly, especially in Indonesia considering that Indonesia is the country with the highest population in Southeast Asia, according to BPS in 2018 the population of Indonesia reaches 266.91 million, but the population distribution is unevenly concentrated on Java. Based on BPS data, the number of residents in DKI Jakarta is 10.5 Million while for East Java Province it is 39.4 Million. The rapid development of the population in Java must be balanced with the fulfillment of the needs of decent housing for each resident, besides the choice of residence is usually adjusted to the proximity of the residence to the workplace, so it is not surprising if the community is concentrated in a downtown or industrial center. This can be felt by the narrowing of available vacant land as a result of the rapid development of industrial and commercial areas which has an impact on the imbalance of supply and demand for land prices and housing prices.
Many factors become the basis for consumers in deciding to buy a house, remembering that a house is a place to live and socialize with the community and build a quality household.

The house is a future palace for someone, in choosing our home, we must be confronted with various considerations and the situation and condition of one's economy, one of the factors that must be observed for someone who wishes to have a house is to pay attention to various aspects such as the distance between the house and the city center or city hall. This is important to note considering the city center is a place that provides a lot of entertainment venues as well as being the center of government, in addition to that must be considered is the access road to the main road. This relates to the ease or access to mobility, both economic and ease in reaching public transportation and public facilities. Before choosing a place to live, it must ensure the availability of electricity, water and telephone connections because electricity is the heart of life for our property. The next step 


\section{Procedia Business and Financial Technology}

Proceedings of the 2nd International Conference on Business and M anagement of T echnology (ICO N BM T 2020) - Part 2

is the area of land, knowing the exact area of land is very important to design the buildings that we have erected besides the area of land can be used as a benchmark for preparing the Budget Plan that we will spend in investing in the property sector.

The choice of raw materials is very much determined by the level of architecture and supporting equipment of a property, a good or beautiful home is very much determined by the architectural design that describes the layout and design of the house as well as the garden, furniture is complementary in giving the owner a beautiful and luxurious impression. The selection of raw materials is the main key to the quality of the house we are going to build so it is no wonder that the quality of a good home is balanced by the costs we will incur.

Estimated house prices are calculated by inserting direct and indirect elements that can affect house prices using the hedonic price method [1] [2] [3] [4] [5]. This method is used to evaluate environmental services where the presence of these services can affect the market price of a house. Factors that can affect the selling price of houses are location characteristics such as land area, building area, number of bedrooms, number of bathrooms, access to health, access to education, water quality [2] [6] [7] [5]. From the various factors above, it is necessary to conduct an in-depth study regarding the factors that need to be considered before consumers choose property, especially in the DKI Jakarta and Surabaya, considering that the city is a metropolitan city with a number of he population is quite large and close to the city center, so it can be seen which factors most influence the selling price of homes in the future.

\subsection{Literature Review and Hypothesis Development}

In some literature reviews in determining the selling price of a house hedonic price method there are differences in research results. There are several uncertainty parameters or results for housing characteristic [8] [6] [9] [3] [7]. For example there are 40 empirical studies examining the number of bedrooms on the selling price of homes, 21 results of the study found that the bedroom has a positive impact on house prices and 9 studies said a negative impact then 10 studies state that there is no significant relationship between the number of bedrooms with prices

Estimates containing uncertainty can confuse market participants. And it is alleged that the characteristics of each housing are not valued equally for the entire distribution of housing prices given by the developer [2] [10] [9]. The buyer can assess the characteristics of each housing differently. So this research compares in two big cities the factors that influence the selling price of a house with the following hypothesis:

H1. Condition 1 has a negative impact on housing prices in the city of Surabaya

$\mathrm{H} 2$. Condition 2 has a negative impact on housing prices in the city of Surabaya

$\mathrm{H} 3$. Electrical has a positive impact on housing prices in the city of Surabaya

H4. Land area has a positive impact on the selling price of homes in the city of Surabaya

H5. The Public Facility has a negative impact on housing prices in the city of Surabaya

H6. Material quality has a positive impact on housing prices in the city of Surabaya

H7. Building area has a positive impact on housing prices in the city of Surabaya

H8. Flood free area has a positive impact on housing prices in the city of Surabaya

H9. Utilities has a positive impact on housing prices in the city of Surabaya

H10. Road type has a positive impact on housing prices in the city of Surabaya

H11. Condition 1 has a negative impact on housing prices in the city of DKI Jakarta

$\mathrm{H} 12$. Condition 2 has a negative impact on housing prices in the city of DKI Jakarta

H13. Electrical has a positive impact on housing prices in the city of DKIJakarta

H14. Land area has a positive impact on housing prices in the city of DKIJakarta

H15. The Public Facility has a negative impact on housing prices in the city of DKIJakarta

H16. Material quality has a positive impact on housing prices in the city of DKI Jakarta

H17. Building area has a positive impact on housing prices in the city of DKI Jakarta

H18. Flood free area has a positive impact on housing prices in the city of DKI Jakarta

H19. Utilities has a negative impact on housing prices in the city of DKIJakarta

H20. Road type has a positive impact on housing prices in the city of DKIJakarta

\subsection{Our Contribution}

This paper examine the main factors that determine housing prices in DKI Jakarta and Surabaya. The paper was conducted to compare factors that affect to the housing prices in that cities. House location, physical facilities and public facilities are the main focus and limit of research in this paper. Contribution our research is beneficial for various parties who have a large role in the housing sector. Buyers of prospective also need to know what factors can impact to housing prices in order to buy a house at a reasonable price or more cheaper.

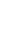




\section{Procedia Business and Financial Technology}

Proceedings of the 2nd International Conference on Business and M anagement of T echnology (ICO N BM T 2020) - Part 2

\subsection{Paper Structure}

The rest of the paper is organized as follows. Section 1 introduces the preliminaries used in this paper, literature review and contribution. Section 2 presents a methodology research. Then, the result in Section 3. Finally, Section 4 concludes the paper and presents direction for future research.

\section{METHODOLOGY}

$50 / 180$

The data of this study uses secondary data, namely documentation and observations contained from online home selling sites, one of which is www.rumah.com and brochure house prices from the developer. Data in the form of data related to home sales data from January 2019 to November 2019. The sample used is 100 home data that represent the type of minimalist to exclusive homes. Based on these data, the operational definitions of the variables are as follows:

Table 1 Definition of operational variables

\begin{tabular}{|c|c|c|}
\hline$\underline{\text { Variable }}$ & Abbreviation & Description \\
\hline & & Dependent \\
\hline Sales Price (Y) & SP & $\begin{array}{l}\text { Selling price of the house set } \\
\text { by the developer (Rp) }\end{array}$ \\
\hline Distance from home to city hall (X1) & Condition 1 & $\begin{array}{l}\text { Distance to home from city } \\
\text { center or city hall }\end{array}$ \\
\hline Distance of house to main road (X2) & Condition 2 & Distance of house to main road \\
\hline Total electrical power (X3) & Electrical & The amount of electric power it has \\
\hline Land area $(\mathrm{X} 4)$ & LSF & Surface area \\
\hline Distance of home to public facilities (X5) & FP & $\begin{array}{l}\text { Distance of home to public } \\
\text { facilities }\end{array}$ \\
\hline Information on home material quality (X6) & & $\begin{array}{l}\text { Dummy variable value of } 1 \text { if } \\
\text { there is material quality } \\
\text { information, and } 0 \text { if not }\end{array}$ \\
\hline Water facilities (X7) & Utilities & $\begin{array}{l}\text { Dummy variable value of } 1 \text { if } \\
\text { PDAM, and } 0 \text { if not }\end{array}$ \\
\hline Road type home location (X8) & Road type & $\begin{array}{l}\text { Dummy variable value of } 1 \text { if } \\
\text { the location is a highway, and } 0 \\
\text { if not }\end{array}$ \\
\hline Flood free (X9) & Flood free & $\begin{array}{l}\text { Dummy variable value of } 1 \text { if } \\
\text { the location is flood free, and } 0 \\
\text { if not }\end{array}$ \\
\hline Building area $(\mathrm{X} 10)$ & BSF & Building area \\
\hline
\end{tabular}

Next will be a multiple regression test using the Minitab

17.0 software to model the selling price of the house [11]. If there is a multicollinearity problem

\section{RESULT}

To do multiple regression tests using the help of MINITAB 17.0. Based on the multiple regression test, the regression model of the house sale price is obtained as follows:

For the selling price of Surabaya city houses

Sale Price $=-2616420532-407252470$ Condition 1 220988380 Condition 2

+1314043 Electrical+ 24779822 LSF 1156189280 public facility +2437663622 Material quality

For the selling price of Jakarta city houses :

$$
\begin{array}{cc}
\text { Sale Price } & =5834065837-590556564 \text { Condition } 2 \\
& +47009220 \text { LSF }-8758423271 \text { Utilities }+ \\
& \text { 5572866336 Road type }
\end{array}
$$

\section{NORMALITY TEST}

The normality test of this research uses Kolmogorov- Smirnov 


\section{Procedia Business and Financial Technology}

Proceedings of the 2nd International Conference on Business and M anagement of T echnology (ICON BM T 2020) - Part 2

where p-values above 0.05 are stated as normally distributed data. Based on the results of data analysis using Minitab 17.0 that variable condition 1 , condition 2 , solved through the analysis of the main components for the sale price electrical, LSF, Public Facility and material quality for the city of Surabaya has a P-Value of 0.160 , which is greater than 0.05 , indicating that these variables have been normally distributed.

\section{Figure 1 Normality Test}

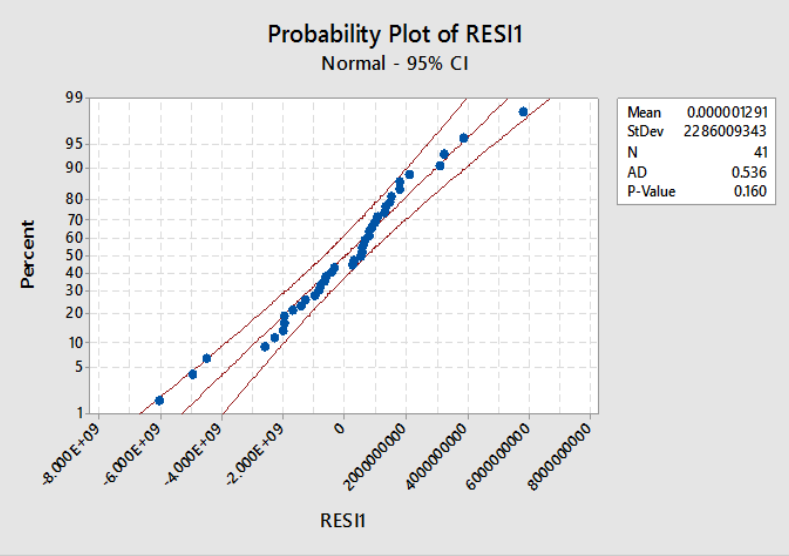

Sumber : Minitab 17.0

Based on the results of data analysis for the city of DKI Jakarta, it was found that the variables have a P-Value of 0.465 , which is greater than 0.05 , which means that the variables are normally distributed.

Figure 2: Normality Test Results

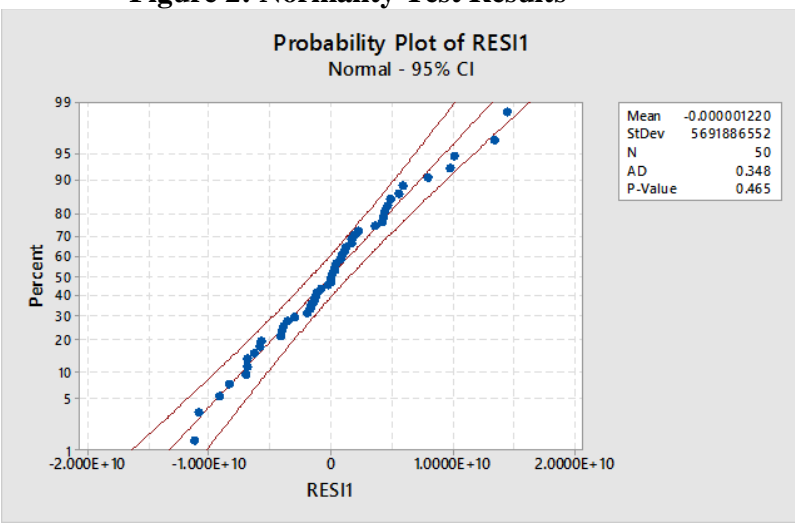

\section{MULTICOLINIERITY TEST}

The results of multicollinearity testing in this study showed a high correlation of relationships between each variable. A good variable is a variable that has no relationship between variables. The results of multicollinearity testing can be seen in table 3 below.
Table 3. Multicollinearity test

$51 / 180$

\begin{tabular}{|c|c|c|c|c|}
\hline No & Effect & Coefficient & $\begin{array}{c}\text { P- } \\
\text { Value }\end{array}$ & Remarks \\
\hline 1 & $\begin{array}{l}\text { Sale Price (0) } \\
\text { Condition 1 }\end{array}$ & $-0,407$ & 0,849 & Unsupported \\
\hline 2 & $\begin{array}{l}\text { Sale Price (0) } \\
\text { Condition } 2\end{array}$ & $-0,220$ & 0,032 & Supported \\
\hline 3 & $\begin{array}{l}\text { Sale Price (0) } \\
\text { Electrical }\end{array}$ & 0,131 & 0,0001 & Supported \\
\hline 4 & $\begin{array}{l}\text { Sale Price (0) } \\
\text { LSF }\end{array}$ & 0,247 & 0,000 & Supported \\
\hline 5 & $\begin{array}{l}\text { Sale Price (0) } \\
\text { Public } \\
\text { Facility }\end{array}$ & $-0,115$ & 0,006 & Supported \\
\hline 6 & Sale Price (1) & 0,243 & 0,255 & Unsupported \\
\hline
\end{tabular}

Table. 5 Hypothesis Test Results for DKI Jakarta City

\begin{tabular}{|c|c|}
\hline \multicolumn{2}{|c|}{ Surabaya City } \\
\hline Term & VIF \\
\hline Condition 1 & 1.16 \\
\hline Condition 2 & 1.14 \\
\hline Electrical & 1.52 \\
\hline LSF & 1.47 \\
\hline BSF & 7.49 \\
\hline Public Facilities & 1.06 \\
\hline Utilities & 1.85 \\
\hline Flood free & 1.54 \\
\hline Material quality & 1.09 \\
\hline Road type & 1.70 \\
\hline \multicolumn{2}{|c|}{ DKI Jakarta City } \\
\hline Condition 1 & 3.50 \\
\hline Condition 2 & 1.32 \\
\hline Electrical & 1.39 \\
\hline LSF & 4.41 \\
\hline BSF & 1.17 \\
\hline Public facilities & 1.47 \\
\hline Utilities & 2.32 \\
\hline Flood free & 3.26 \\
\hline Material quality & 3.46 \\
\hline Road type & 1.85 \\
\hline
\end{tabular}

The table above shows the results of multicollinearity testing of all variables in two cities free from multicollinearity.

\section{HYPOTHESIS TESTING}

Table. 4 Hypothesis Test Results for Surabaya City

\begin{tabular}{|c|l|l|c|c|}
\hline No & \multicolumn{1}{|c|}{ Effect } & Coefficient & $\begin{array}{c}\text { P- } \\
\text { Value }\end{array}$ & $\begin{array}{l}\text { Remark } \\
\text { S }\end{array}$ \\
\hline 1 & $\begin{array}{l}\text { Sale Price (0 } \\
\text { Condition 1 }\end{array}$ & $-0,407$ & 0,035 & Supported \\
\hline 2 & $\begin{array}{l}\text { Sale Price (0 } \\
\text { Condition 2 }\end{array}$ & $-0,220$ & 0,060 & $\begin{array}{l}\text { Unsupport } \\
\text { ed }\end{array}$ \\
\hline
\end{tabular}




\section{Procedia Business and Financial Technology}

Proceedings of the 2nd International Conference on Business and M anagement of T echnology (ICO N BM T 2020) - Part 2

\begin{tabular}{|c|l|l|l|l|}
\hline 3 & $\begin{array}{l}\text { Sale Price (0) } \\
\text { Electrical }\end{array}$ & 0,131 & 0,0001 & Supported \\
\hline 4 & $\begin{array}{l}\text { Sale Price (0) } \\
\text { LSF }\end{array}$ & 0,247 & 0,0001 & Supported \\
\hline 5 & $\begin{array}{l}\text { Sale Price (0 } \\
\text { Building } \\
\text { area }\end{array}$ & $-0,115$ & 0,006 & Supported \\
\hline 6 & $\begin{array}{l}\text { Sale Price (0) } \\
\text { Flood free }\end{array}$ & 0,243 & 0,013 & Supported \\
\hline 7 & $\begin{array}{l}\text { Sale Price (0) } \\
\text { Public } \\
\text { Facility }\end{array}$ & $-0,590$ & 0,0001 & Supported \\
\hline 8 & $\begin{array}{l}\text { Sale Price (0) } \\
\text { Utilities }\end{array}$ & 0,470 & 0,0001 & Supported \\
\hline 9 & $\begin{array}{l}\text { Sale Price (0 } \\
\text { Material } \\
\text { Quality }\end{array}$ & $-0,875$ & 0,004 & Supported \\
\hline 10 & $\begin{array}{l}\text { Sale Price } \\
\text { (0Road type }\end{array}$ & 0,557 & 0,030 & Supported \\
\hline
\end{tabular}

\begin{tabular}{|c|l|l|l|l|}
\hline & $\begin{array}{l}\text { Material } \\
\text { quality }\end{array}$ & & & \\
\hline 7 & $\begin{array}{l}\text { Sale Price (0 } \\
\text { Condition 3 }\end{array}$ & $-0,590$ & 0,02 & Supported \\
\hline 8 & $\begin{array}{l}\text { Sale Price } \\
\text { () LSF }\end{array}$ & 0,470 & 0,01 & Supported \\
\hline 9 & $\begin{array}{l}\text { Sale Price } \\
\text { (0) Utilities }\end{array}$ & $-0,875$ & 0.004 & Supported \\
\hline 10 & $\begin{array}{l}\text { Sale Price } \\
\text { (O) Road } \\
\text { type }\end{array}$ & 0,557 & 0.030 & Supported \\
\hline
\end{tabular}

Based on the results of the hypothesis test in table 4 and 5 above, it appears that the variable condition 1, which is the distance between the house and the cityhall, affects the selling price of houses in the city of Surabaya with a coefficient value of 0.407 and a p-value of 0.035 . That indicates that the farther the distance from the house to the city hall, the lower the selling price of the house, and vice versa the closer the house to the city hall, the more expensive the selling price of the house.

The condition 2 variable also affects the sale price which shows a coefficient value of -0.220 and a p-value of 0.060 , which means that the farther the distance of the house from the main road, the cheaper the price of housing in Surabaya. That is related to the ease of transportation of homeowners in carrying out activities outside the home. From the table above it can be seen that the electrical variable has a positive impact on the sale price, indicated by a coefficient value of 0.131 and a p-value of 0.0001 . That indicates that the higher the level of electrical power owned by a house in Surabaya, the higher the selling price as well. This is in line with the ability of the house to accommodate equipment that requires electricity.

The LSF variable also has a positive effect on the sale price, with a coefficient of 0.247 and a p-value of 0.0001 . This means that the higher the land area, the more expensive housing prices in Surabaya. Next, the public facility variable has a coefficient value of -0.115 and a $p$ value of 0.006 . Variable public facility has a negative impact on housing prices in Surabaya. The closer the house is to the public facilities, the more expensive the selling price of the house. The further the distance of the house from public facilities, the cheaper the price of the house. This is related to easy access to schools, shopping and playing as well as health facilities. So the closer the distance the more expensive the price of the house.

The selling price of a house is also influenced by material quality. Shown with a coefficient value of 0.243 and a pvalue of 0.013 . Indicates that the more information disclosed by a home sale site, the selling price of the house is expensive. If there is no information related to the quality of home materials, the price of the house is getting cheaper. So the sixth hypothesis is supported.

Variable independent condition 2 affects the selling price of houses in DKI Jakarta. Shown with a coefficient value of -

0.590 and p-value of 0.0001 . This indicates that the farther the distance of the house from the main road, the selling price of the house in the city of DKI Jakarta is more expensive. This is in line with findings in the city of Surabaya.

The table above shows the LSF variable has a coefficient value of 0.470 and a p-value of 0.0001 . The variable land area has a positive effect on the selling price of houses in DKI Jakarta and in Surabaya. The more land is sold, the more expensive the selling price of the house.

Utilities has a negative effect on the selling price of houses in DKI Jakarta. Shown with a coefficient of -0.875 and a $\mathrm{p}$ - value of 0.004 . That means that if the house sold is equipped with PDAM water, the selling price of the house will be more expensive in Jakarta. If a house has no PDAM, the selling price of the house is cheaper.

Variable road type has a positive effect on house prices. With a coefficient of 0.557 and a p-value of 0.030 . This indicates that if the location of the house being sold is a highway, the selling price of the house will be more expensive. But if the location of the house is in a small alley, the selling price of the house is getting cheaper.

\section{CONCLUSION}

This research discusses about the comparative analysis of factors affecting the selling price of houses between DKI Jakarta and Surabaya. Based on the results of the regression test above, it can be concluded that the factors that affect the selling price of houses in big cities, namely Surabaya and DKI Jakarta, are strongly influenced by easy access to transportation, easy access to education, health, entertainment, and other interests, in addition to facilities owned by the house and the level of electric power. also, affect the selling price of the house.

From this research, property developers and property 


\section{Procedia Business and Financial Technology}

Proceedings of the 2nd International Conference on Business and M anagement of T echnology (ICO N BM T 2020) - Part 2

agents can have a better knowledge of factors that may increase home prices, while prospective homebuyers can have a better idea of a reasonable price range. For further research, it is recommended to investigate the macroeconomy factor and tax regulation as determinants of the house price. Also, further research may be done in big cities other than Jakarta and Surabaya

\section{REFERENCES}

[1] M. Z. Asmawi, N. M. Noor, M. Nasrul, H. Manzahari, and A. Abdullah, "The Relationship Between Open Spaces and House Prices in Selected Townships in Kuala Lumpur, Malaysia," in Proceedings of SOCIOINT14-International Conference on Social Sciences and Humanities, 2014, pp. 1057-1066.

[2] S. Brauckmann and A. Ciarlone, "City tourism and the sharing economy- potential effects of online peer-to-peer marketplaces on urban property markets," Journal of Tourism Futures, vol. 3, no. 2, pp. 17-52, 2017, doi: 10.1108/SEF-11-20130170.

[3] V. Limsombunchai, "House Price Prediction: Hedonic Price Model vs," 2004.

[4] M. A. Mohit, M. Ibrahim, and Y. R. Rashid, "of residential satisfaction in newly designed public low-cost housing in Kuala Lumpur , Malaysia," Habitat International, vol. 34, no. 1, pp. 18-27, 2010, doi: 10.1016/j.habitatint.2009.04.002.

[5] J. Zietz, E. N. Zietz, and G. S. Sirmans,
"Determinants of House Prices: A Quantile Regression Approach," Journal of Real Estate Finan Econ, vol. 37, pp. 317-333, 2008, doi: 10.1007/s11146-007-9053-7.

[6] N. Girouard, M. Kennedy, P. V. D. Noord, and C. André, "Recent House Price Developments : The Role of Fundamentals," OECD Economics Department Working Papers, vol. 475, 2006.

[7] P. D. Vries and P. Boelhouwer, "Local house price developments and housing supply," Property Management, vol. 23, no. 2, pp. 80-96, 2005, doi: $10.1108 / 02637470510589968$.

[8] G. Fan, S. E. Ong, and H. C. Koh, "Determinants of House Price: A Decision Tree Approach," Urban Studies, vol. 43, no. 12, pp. 2301-2315, 2006.

[9] B. Keskin, "Hedonic analysis of price in the istanbul housing market," International Journal of Strategic Property Management, vol. 12, no. 2, pp. 125-138, 2008, doi: 10.3846/1648-

[10] J. Hahn, J. Hirsch, and S. Bienert, "Does ' clean ' pay off? Housing markets and their perception of heating technology," Property Management, vol. 36, no. 5, pp. 575-596, 2018, doi: 10.1108/PM-082017-0051.

[11] G. Smith, "Learning Statistics by Doing Statistics 2 . Working With Data," Journal of Statistics Education,6(3, 1998, doi: 10.1080/10691898.1998.11910623. 